\title{
Enhancement the Osseo Integration Properties of Polymer for Human Body Implants
}

\author{
Dhurgham Majid Rasheed ${ }^{1}$, Dunya Abdulsahib Hamdi ${ }^{2}$
}

\section{Authors affiliations: \\ 1) Prosthetics \& Orthotics Eng. Dept., College of Engineering, Al-Nahrain University, Baghdad, Iraq Dhurgham.alzubiady@yahoo.com}

2*) Prosthetics \& Orthotics Eng. Dept., College of Engineering, Al-Nahrain University, Baghdad, Iraq dunia_sh 7@yahoo.com

\section{Paper History:}

Received: $13^{\text {th }}$ Dec. 2019

Revised: $2^{\text {th }}$ Jan. 2020

Accepted: $16^{\text {th }}$ July 2020

\begin{abstract}
In this research, polymer polymethyl methacrylate PMMA composite with nano ceramic $\mathrm{Zr}$ and HAp material were used to manufacture one part of the implant system (femoral ball head of hip implant). Three set of hybrid materials were fabricated and tested for this study; the first mixtures which contains 100\% (PMMA), the second mixtures which contains (90\% (PMMA) $+8 \%(\mathrm{Zr})+2 \%$ (HAp)), and the third mixtures which contains $(80 \%$ (PMMA) $+18 \%(\mathrm{Zr})+2 \%$ (HAp)) were investigated. The mechanical properties for these mixtures increased with the increasing of nano ceramic concentration ( $\mathrm{Zr}$ and HAp) composite material in the polymer compared to pure polymer PMMA sample. However, an increase in the concentration of $\mathrm{Zr}$ from $8 \%$ to $18 \%$ content cause a considerable decrease of the hardness where a drop of homogeneity in Zr- matrix PMMA contact occurred, V Hardness value are $(68,80$ and 70$) \mathrm{Kg} . \mathrm{mm}$ for three mixture respectively. The wear test was in agreement with results of the hardness test. The weight loss of the above samples of the wear test were (0.041, 0.035 and 0.037) respectively. According to mechanical properties, the best sample contains (90\% (PMMA) $+8 \%(\mathrm{Zr})+2 \%(\mathrm{HAp}))$. The Scanning electron microscopy resolute showed the particles forming semi-continuous network along grain boundaries polymer for second sample mixtures containing $(90 \%$ (PMMA) $+8 \%(\mathrm{Zr})+2 \%(\mathrm{HAp}))$, provides a low atomic packing and high energy. This will make the grain boundaries more reactive and strengthen mechanical performance. The Optical microscopy, Scanning electron microscopy and Xray spectroscopy analysis for In vitro test using SBF shows the growth of HAp layer with an increase in concentration of $\mathrm{Ca}$ and $\mathrm{P}$ elements formed on the surface of the second sample. This display of good results is a proof of the biocompatibility of the polymer sample.
\end{abstract}

Keywords: Polymer, Polymethyl Methacrylate, Zr, Hydroxyapatite, Composite, Solid Work.

$$
\begin{aligned}
& \text { تحسين خصائص الالفة الاحيائية للبوليمر لزراعتها في جسم الانسان }
\end{aligned}
$$

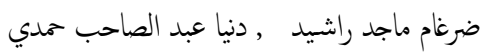

$$
\begin{aligned}
& \text { في هذا البحث، تم استخدام مادة بولميمر بولى ميثيل ميثكريبيت PMMA المركب مع مادة نانو سيراميك }
\end{aligned}
$$

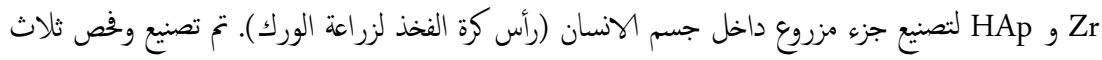

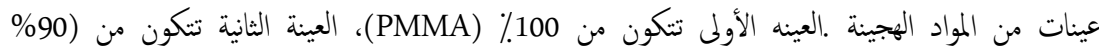

$$
\begin{aligned}
& \text { PMMA) + 18\% (Zr) + 2\% ( ) (PMMA) + 8\% (Zr) + 2\%(HAp) }
\end{aligned}
$$

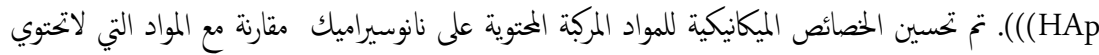

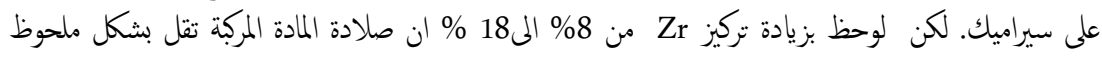

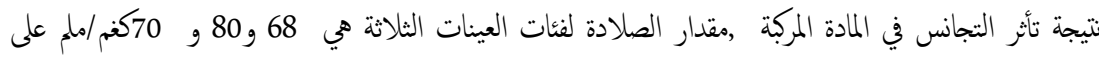

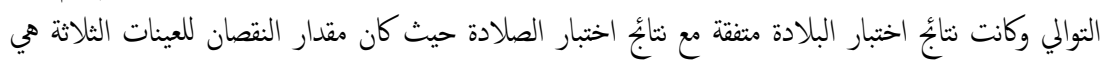




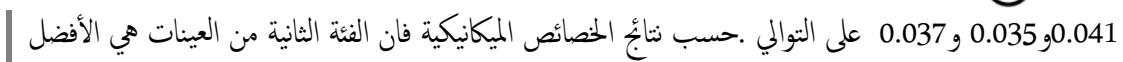

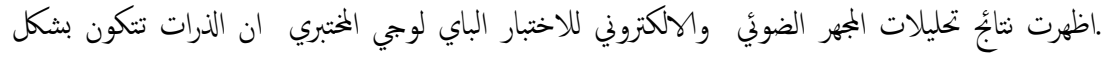

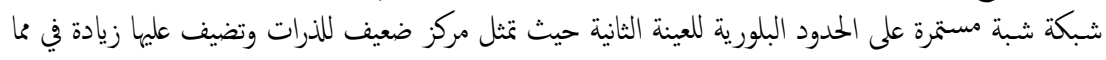

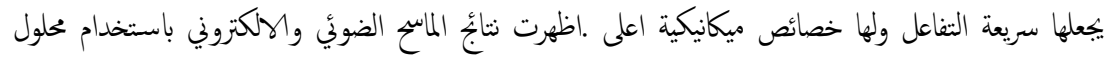

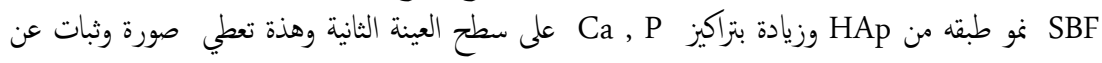

$$
\begin{aligned}
& \text { النكمل الحيوي للعينة. }
\end{aligned}
$$

\section{Introduction}

In recent years, many polymers, such as (PMMA, PEEK, PVC...etc.) are largely used for biomedical applications. (PMMA) polymethyl methacrylate has been used as a self-polymerising bone cement in orthopaedics since the 1960s due to its light, white high melting point, and strength compared with other polymers, as well as resistance to chemical and biological functions, and biocompatibility properties [1-2]. The low mechanical properties of PMMA polymer was a limitation in the clinical application for restorative materials. So that the several methods were applied to enhance or to improve the mechanical properties of PMMA, such as the addition of structural component including metal, ceramic (zirconia, silica, alumina ...etc.), by adding fiber particles with different elements and size such as CNT and copper to PMMA[3]. Z Hasratiningsih et al investigated the hardness of PMMA reinforced with $\mathrm{ZrO}_{2}-\mathrm{Al}_{2} \mathrm{O}_{3}-\mathrm{SiO}_{2}$ filler system at two different calcination temperatures (at $550^{\circ} \mathrm{C}$ and $700^{\circ} \mathrm{C}$ for 1hour) using different ratios polymer of PMMA powder $(7,9,11,13$ and $15 \mathrm{wt} \%)$. The results showed the PMMA sample exhibiting the highest hardness about $13 \%$ and $700^{\circ} \mathrm{C}$ [4]. Shinzato $\mathrm{S}$ et al evaluated the biological and mechanical properties of composites consisting of PMMA and different types of phase alumina powder. They found out that the $\mathrm{Al} 2 \mathrm{O} 3$ allowed direct bone formation on their surfaces and enhanced the mechanical properties such as strength and Young's modulus [5]. D.E. Discher et al studied the effect of addition hydroxyapatite, Carbon nanotube to polymer PMMA as composite material used in bone bridges or internal orthopedic surgery. They found that the HAp have ability to bond with tissues, and the carbon nanotube is strongest and stiffest materials [6]. MythillibTi-6Al-4V was investigate the using of nano Hydroxyapatite (HAp) is a nano ceramics coating $\mathrm{Ti}$ alloy for orthopedic and dental applications, which gives better Osseo integration [7]. Vopat et al was study use the polymer material interference screws for ligament fixation implant due to important properties of biocompatibility[8] . Arisara Thaveedeetrakul et al was investigate the bioactive and microstructure properties of thin film Zirconia deposited on $316 \mathrm{~L}$ still steel using DC sputtering for medical application [9] . C. Piconi and G. Maccauro were investigate Clinical properties of $\mathrm{ZrO} 2$ thin films are could formed a bone substitutes with environment even under highly loaded conditions such as femoral and knee joint since they exhibit high fracture toughness as well as high bondbonding ability [10].
Emre $G$ et al investigated tribological and mechanical (such as wear) properties of keratin, bone ash and hydroxyapatite by adding to PMMA (known as the main prosthesis material) $(\% 1, \% 3$ and $\% 5$, respectively). It was observed that, improvement in mechanical properties of the PMMA including $5 \%$ of keratin, bone ash and hydroxyapatite [11]. Wesam et al were investigated experimentally and theoretically the enhancement of mechanical and microstructure properties of the composite material (PMMA + AL2O3 + CF) that used in manufacturing internal Orthopaedic [12]. The aim of this work is using polymer PMMA composite with nano ceramic Zr and HAp material for manufacturing part of implant system (femoral ball head of hip implant) in human body with improving the mechanical and biocompatibility properties of the composite. A solidwork program and $3 \mathrm{D}$ printer was used to production model femoral ball head of hip implant system from best composite materials.

\section{Materials}

The polymer PMMA acrylic poly nano size (methyl 2methylpropenoate) has chemical formula $(\mathrm{C} 5 \mathrm{H} 8 \mathrm{O} 2) \mathrm{n}$ provided from (Czech Republic jerman)used as matrix. Zirconium $(\mathrm{Zr})$, with (purity $99.0 \%$ and particle size $40-60 \mathrm{~nm})$, and Hydroxyapatite (HAp) with (purity $99.0 \%$ and particle size $40 \mathrm{~nm}$ ) were provided from Sky Spring Nanomaterial's and used as reinforced material.

\section{Experimental Methods}

Figure (1) shows a diagram for the plan of experimental works. The typical procedure, polymer (PMMA) as matrix reinforced by ceramics $(\mathrm{Zr})$ and (HAp)with different concentration .The ceramics partial are mixing by using mix char. Three mixtures are operated, the first mixtures contains 100\% (PMMA), second mixtures contain (90\% (PMMA) + $8 \%(\mathrm{Zr})+2 \%(\mathrm{HAp}))$, and third mixtures contain $(80 \%$ (PMMA) $+18 \%(\mathrm{Zr})+2 \%$ (HAp)). The addition concentration was depend on literature review[9] .Each samples are pressed in mold with under air using ultrasonic to reduce the air ball during molding. A standard dimension mold were use (length140mm, width $13 \mathrm{~mm}$ and thickness $3 \mathrm{~mm}$ ) for V Hardness dimension and (length200 $\mathrm{mm}$ and width $100 \mathrm{~mm}$ ) for wear tests. All above samples are designed under air pressure using ultrasound. Six sample are suggested from Nain samples due to mechanical tests. 


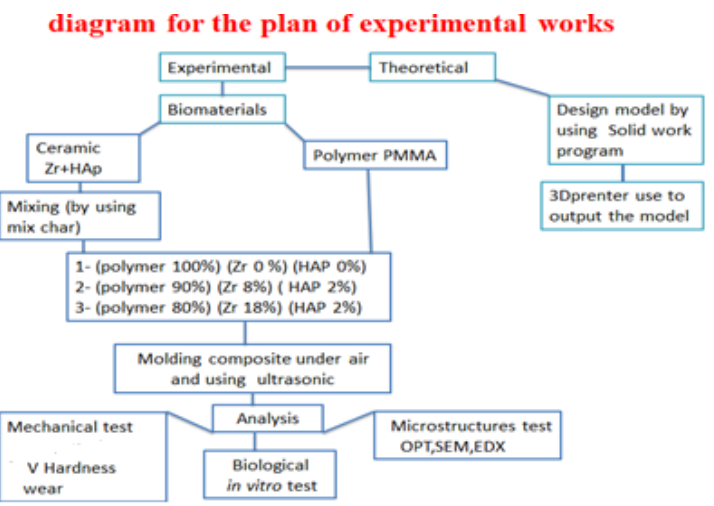

Figure (1): Diagram for the plan of experimental works.

\section{Theortical}

Figure (2. a) shows the schematic view of total hip replacement [13]. The part of femoral ball head of implant system in human body are drawn by using (solid work) as shown in Fig. (2.b), processed according to a default pattern in three dimensions (reds $4 \mathrm{~cm}$ and thickness $3 \mathrm{~mm}$ ). The aim of drawing models by solid work is to use $3 \mathrm{D}$ printer to produce the mold as shown in Fig. (2.c) which use for production model of femoral ball. Fig. (2.d), production model femoral ball head of hip implant system from best composite materials (90\% PMMA $+8 \% \mathrm{Zr}+2 \%$ HAp).

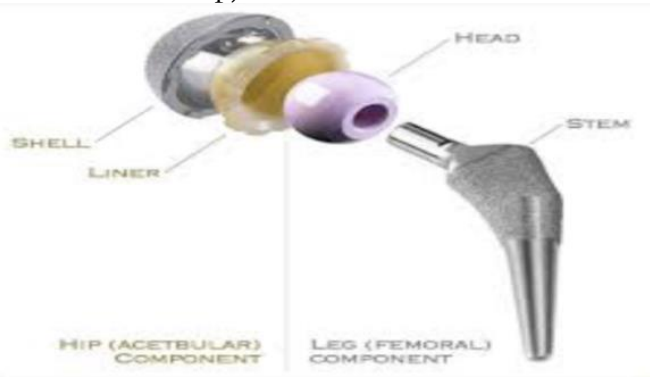

(a)

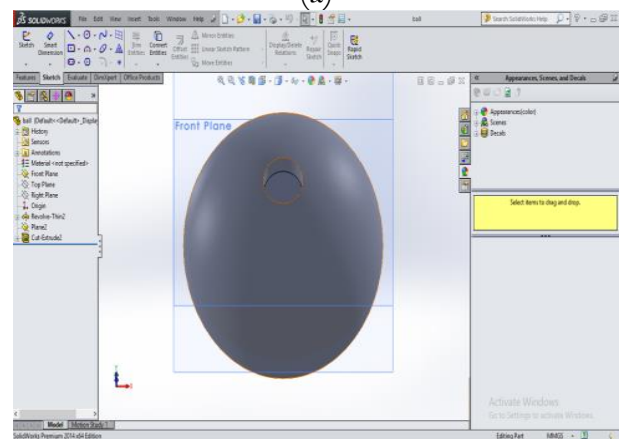

(b)

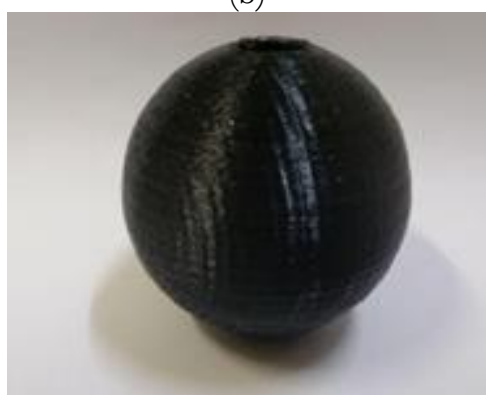

(c)

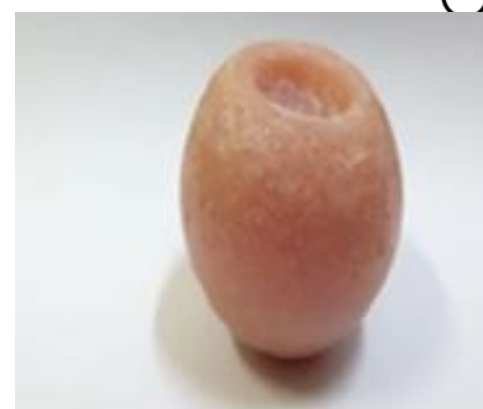

(d)

Figure (2): (a) Schematic view of total hipreplacement [3] (b) a femoral ball head of implant system in human body drawn by using solid work program.(c) use 3D printer to produce mold (d) production model femoral ball head of hip implant system from best composite materials (90\% $\%$ PMA $+8 \% \mathrm{Zr}+2 \% \mathrm{HAp})$.

\section{Results and Discussion}

\subsection{Mechanical tests:}

\section{A- V Hardness test}

Mechanical properties are utilized for find the samples properties, Vickers hardness was used to test the samples with a Load applied on the surface $=9.8$ $\mathrm{N}$ for $20 \mathrm{sec}$ [14]. The formula used for calculating the Vickers Hardness Number equation (1),

$$
\mathrm{HVP}=1.8544 * \mathrm{P} / \mathrm{d} 2 \ldots \ldots \ldots \ldots . .(1)
$$

Where $\mathrm{P}=$ force (load) in kilograms, $\mathrm{d}=$ diagonal length of the impression in $\mathrm{mm}$ (millimeters)

Table (1):V Hardness of pure and PMMA composite

\begin{tabular}{|c|c|c|c|}
\hline $\begin{array}{c}\text { Test } \\
\text { points }\end{array}$ & $\begin{array}{c}(100 \% \\
\text { PMMA }) \\
(\text { Kg.mm }) \\
(1)\end{array}$ & $\begin{array}{c}(90 \% \text { PMMA } \\
+8 \% \mathrm{Zr}+ \\
2 \% \mathrm{HAp}) \\
(\text { Kg.mm })(2)\end{array}$ & $\begin{array}{c}(80 \% \text { PMMA + } \\
18 \% \mathrm{Zr}+2 \% \\
\mathrm{HAp}) \\
(\mathrm{Kg} \cdot \mathrm{mm})(3)\end{array}$ \\
\hline up & 65 & 79 & 74 \\
\hline mid & 70 & 82 & 80 \\
\hline down & 69 & 78 & 77 \\
\hline mean & 68 & 80 & 77 \\
\hline
\end{tabular}

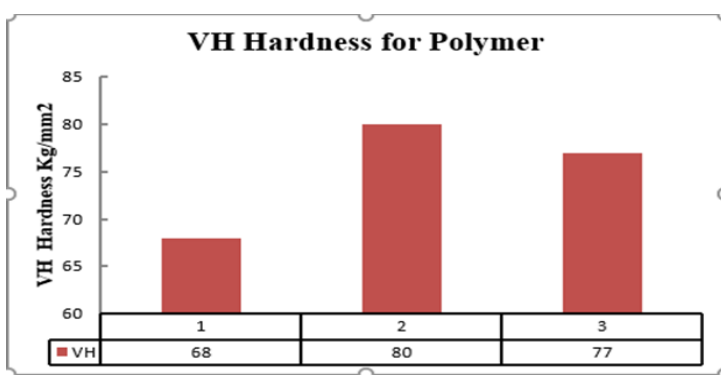

Figure (3): V Hardness of pure and PMMA composite

The value of $\mathrm{V}$ Hardness has been tested for three points up, mid and down for each samples. From the results in Table (1) and Fig. (3), the addition Nano ceramic ( $\mathrm{Zr}$ and HAp) composite material for polymer was increasing from the value of $\mathrm{V}$ hardness of samples compare to pure polymer PMMA sample. This increase in hardness was possibly belong to characteristics of $\mathrm{Zr}$ and HAp. Especially Zr, which has very high mechanical 
properties hardness. But an increase in concentration of $\mathrm{Zr}$ from $8 \%$ to $18 \%$ content yields a considerable decrease of the hardness where a drop of homogeneity in Zr- matrix PMMA contact accurse.

\section{B- Wear test}

The experiments made are based on the unit obtained by applying abrasive discs which rotate at $337 \mathrm{rpm}$, for three samples with conditions $\mathrm{F}=47 \mathrm{~N}$, $\mathrm{V}=0.5 \mathrm{~m} / \mathrm{s}$ and $\mathrm{t}=3 \mathrm{~min}[15]$. The specimens dimension were D: $12.7 \mathrm{~mm}$, L: $12.7 \mathrm{~mm}$, as ASLE (American Society of Lubrication Engineers). The most commonly used "weight difference method". The weight of sample was calculated before doing the wear test, then they were in the wear device for three minutes with above condition and removed it from the devices, calculated the weight again and returned the sample to the device and for three minutes also. Three tests results was available for the final weight loss the accumulative wear results .Table (2) shown the weight loss results of wear test of pure and PMMA composite, the homogeneity and porous of the powdered samples have an important role on the wear performance of the material, the best sample contain $(90 \%$ (PMMA) $+8 \%(\mathrm{Zr})+2 \%(\mathrm{HAp}))$. The increasing in concentration adding of ceramic particle had bad affected on the results of wear, which in agreement with results of hardness test.

Table (2): The weight loss of the sample of Wear test for pure and PMMA composite.

\begin{tabular}{|c|c|c|c|}
\hline $\begin{array}{c}\text { No. of } \\
\text { test }\end{array}$ & $\begin{array}{c}(100 \% \\
\text { PMMA) }\end{array}$ & $\begin{array}{c}\text { (90\% PMMA } \\
+8 \% \mathrm{Zr}+ \\
2 \% \mathrm{HAp})\end{array}$ & $\begin{array}{c}\text { (80\% PMMA } \\
+18 \% \mathrm{Zr}+ \\
2 \% \mathrm{HAp})\end{array}$ \\
\hline 1 & 0.021 & 0.018 & 0.019 \\
\hline 2 & 0.041 & 0.035 & 0.037 \\
\hline 3 & 0.061 & 0.053 & 0.056 \\
\hline mean & 0.041 & 0.035 & 0.037 \\
\hline
\end{tabular}

\subsection{Microstructure analysis \\ A- Optical Microscope}

The optical microstructure with magnification of $500 \mu \mathrm{m}$ examination used to invented the dispersion of bioactive particles the PMMA matrix pure and interfacial bonding between matrix and reinforced particles $(8 \% \mathrm{Zr}+2 \% \mathrm{HAp})$ is shown in Fig.(4). As appear in Fig. (4.a), the air bubbles are formed in pure polymer and no crack has been detected, the formation of air bubbles in pure polymer (PMMA) is formed due to the hand mixing as appear previously in the work of Hamdi et al.[16] . While Fig. (4.b) polymer matrix composite provides good indication in evaluation of surface morphology, agglomeration and full distribution of nanoparticles.

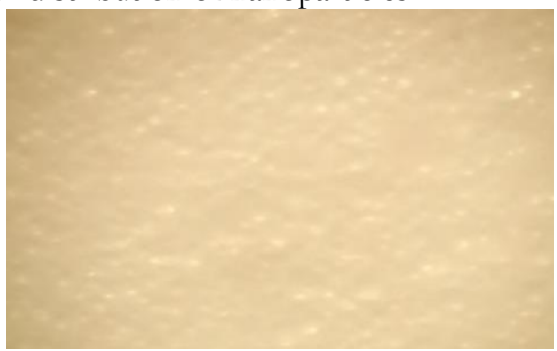

(a)

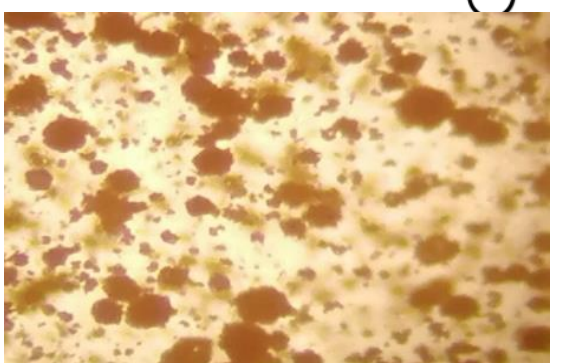

(b)

Figure (4): Optical microscopy before In vivo test for(a) Pure polymer PMMA with formation of air bubbles,(b) agglomeration and full distribution for composite $(90 \% \mathrm{PMMA}+8 \% \mathrm{Zr}+2 \% \mathrm{HAp})$

\section{B- SEM and EDX}

Figure (5) scanning electron microscopy (SEM) type (JESCAN-Vega III) was used to displaying the topography of surface of samples and the energy dispersive X-ray analysis (EDXA) which connect parallel with SEM, used to description the chemical characterization or elemental analysis of a sample, as shown in Fig.(6). The air bubbles have size approximately $(1-3 \mu \mathrm{m})$ was very clear for pure polymer in Fig. (5.a) which specify the results of optical microstructure Fig. (4.a). Fig. (5.b) ceramic particles ( $\mathrm{Zr} \& \mathrm{HAp})$ dispersed in the PMMA matrix the intermediate state [17]. The particles forming semi-continuous network along grain boundaries polymer provides low atomic packing and high energy which making the grain boundaries more reactive and strength mechanical performance [18].

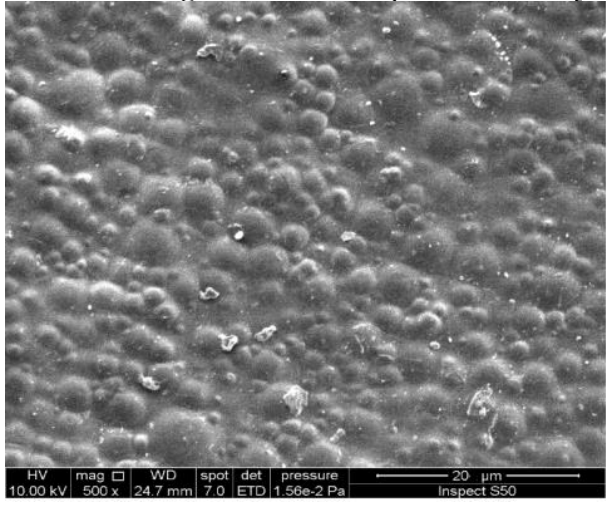

(a)

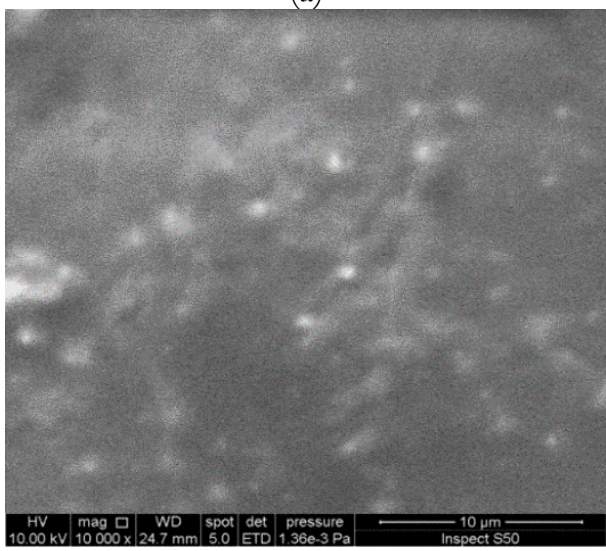

(b)

Figure( 5): SEM before In vivo test for (a)Pure polymer PMMA with formation of air bubbles, (b) composite $(90 \% \mathrm{PMMA}+8 \% \mathrm{Zr}+2 \% \mathrm{HAp})$ particles forming semi-continuous network along grain boundaries. 
Figure (6.a) Pure polymer PMMA, the energy dispersive $\mathrm{X}$-ray analysis, the energy transitions element $\mathrm{O} \mathrm{K} \alpha$ are $0.5 \mathrm{KeV}$, and $\mathrm{K} \alpha 0.277 \mathrm{KeV}$ for element C. Fig.(6.b) for composite (90\% PMMA + $8 \% \mathrm{Zr}+2 \% \mathrm{HAp})$ the major elements $\mathrm{Ca}$ and $\mathrm{P}$ belong to HAp material. The energy transitions $\mathrm{K} \alpha$ are $3.69 \mathrm{KeV}$ and $\mathrm{L} \alpha 0.341 \mathrm{KeV}$ for elements $\mathrm{Ca}, \mathrm{P}$ $\mathrm{K} \alpha$ are $2.01 \mathrm{KeV}$ and $\mathrm{L} \alpha 2.01 \mathrm{KeV}$ for element $\mathrm{Zr}$. The element $\mathrm{Au} \mathrm{M} \alpha$ with energy of $2.12 \mathrm{KeV}$ due to coated the samples with gold for high resolution SEM analysis [19].

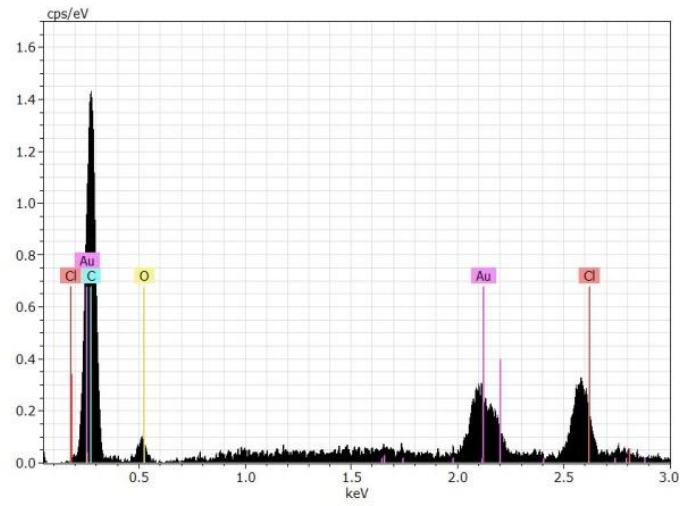

(a)

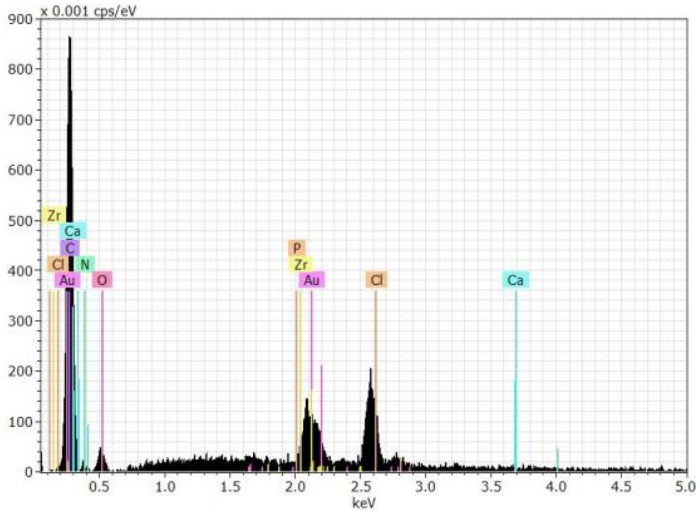

(b)

Figure (6): EDX concentration elements before In vivo test for(a) Pure polymer PMMA,

(b)composite $(90 \% \mathrm{PMMA}+8 \% \mathrm{Zr}+2 \% \mathrm{HAp})$.

\subsection{In vitro Test}

The In vitro test biocompatibility properties were tested by immersed composite $(90 \% \mathrm{PMMA}+8 \% \mathrm{Zr}$ $+2 \% \mathrm{HAp}$ ) samples for one month in SBF the HP 7.6 with material concentration elements as in Shinn-Jyh Ding [20]. Fig.(7) and Fig.( 8.a) shows the growth of HAp layer formed bio mimetically on the surface for composite $(90 \% \mathrm{PMMA}+8 \% \mathrm{Zr}+2 \% \mathrm{HAp})$ analysis by Optical microscopy and SEM respectively. This shows good results proof the biocompatibility of the polymer. Fig. (8.b) the elements of SBF were very clear in EDX analysis, $\mathrm{Mg}$ with energy transitions $\mathrm{K} \alpha$ $1.25 \mathrm{KeV}, \mathrm{K} \alpha 3.3 \mathrm{KeV}$ for $\mathrm{K}$ element and $\mathrm{K} \alpha 1.040$ $\mathrm{KeV}$ for $\mathrm{Na}$ element. The intensity elements $\mathrm{Ca}$ and $\mathrm{P}$ was increasing which belong to HAp layer growth on the sample after immersion.

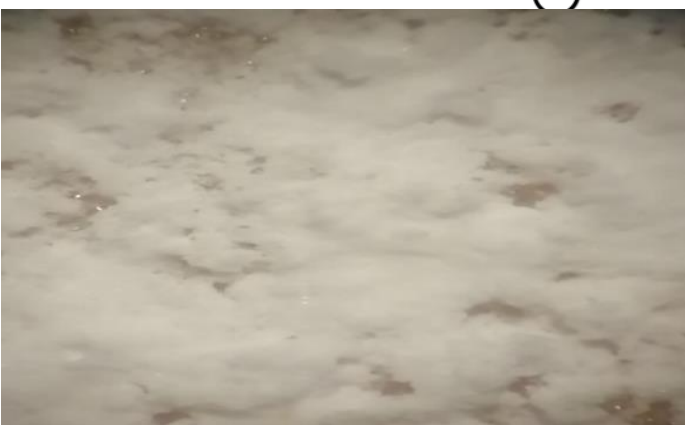

Figure (7): Optical microscopy after In vitro test for composite $(90 \% \mathrm{PMMA}+8 \% \mathrm{Zr}+2 \% \mathrm{HAp})$ with growth Hap layer.

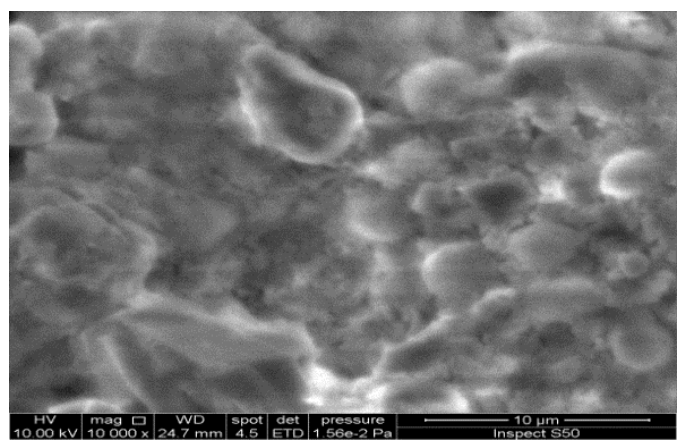

(a)

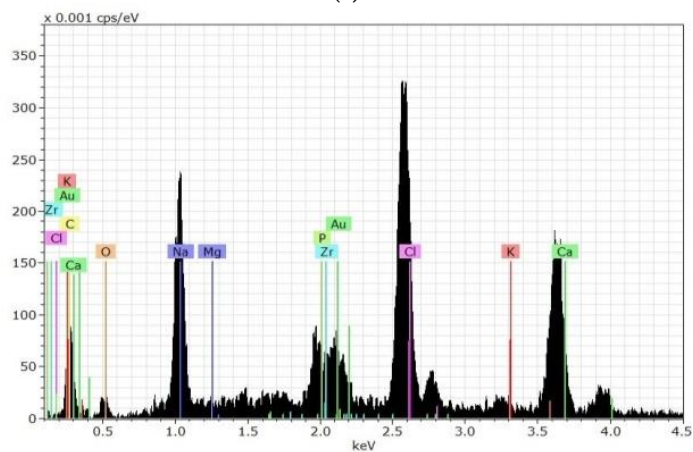

(b)

Figure (8): (a) SEM and (b) EDX after In vivo test for composite (90\% PMMA + 8\% $\mathrm{Zr}+2 \%$ HAp) with growth of HAp layer formed bio mimetically on the surface.

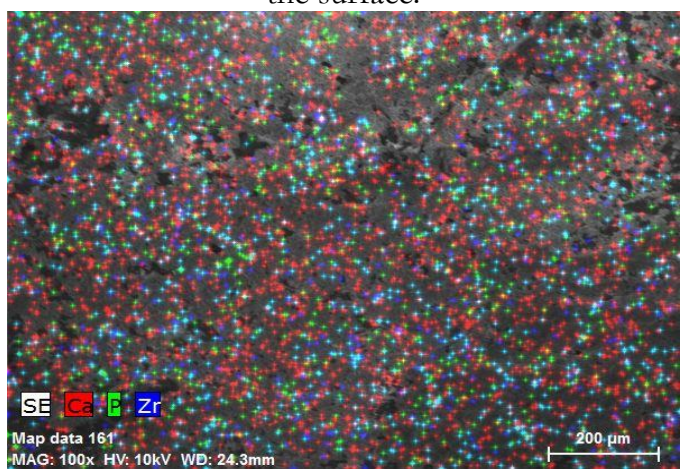

Figure (9): EDX map for composite $(90 \% \mathrm{PMMA}+8 \% \mathrm{Zr}+2 \% \mathrm{HAp})$ with particles $(\mathrm{Zr}, \mathrm{P}$ and $\mathrm{Ca}$ ) dispersed state in a matrix PMMA.

Figure (9) represent the map data distribution of Nano-particles composite for (90\%PMMA $+8 \% \mathrm{Zr}+2 \% \mathrm{HAp}$ ). The particles ( $\mathrm{Zr}, \mathrm{P}$ and $\mathrm{Ca}$ ) dispersed state in a matrix PMMA, which increase 
from mechanical strength properties such hardness and wear.

\section{Conclusions}

1-Three sets of hybrid material for this study the first mixtures contain 100\% (PMMA), the second mixtures contain $(90 \%$ (PMMA) $+8 \%(\mathrm{Zr})+2 \%$ (HAp)), and the third mixtures contain (80\% $(\mathrm{PMMA})+18 \%(\mathrm{Zr})+2 \%(\mathrm{HAp}))$ were microstructure and mechanical fabricated and investigated.

2-The mechanical (V Hardness and wear) results was improved with addition of nano ceramic ( $\mathrm{Zr}$ and HAp) composite material for polymer compare to pure polymer PMMA sample.

3 -The increase in concentration of $\mathrm{Zr}$ from $8 \%$ to $18 \%$ content yields a considerable decrease of the hardness where a drop of homogeneity in $\mathrm{Zr}$ - matrix PMMA contact accurse, ( $V$ Hardness value are: $80 \mathrm{Kg} . \mathrm{mm}$ and $70 \mathrm{Kg} . \mathrm{mm})$ for second and third mixture respectively. The wear test in agreement with results of hardness test, the weight loss of the above samples of the wear test are (0.035 and 0.037) respectively.

4- For composite (90\% (PMMA) + 8\% ( $\mathrm{Zr})+2 \%$ (HAp)), The particles ( $\mathrm{Zr}, \mathrm{P}$ and $\mathrm{Ca}$ ) distribute or forming semi-continuous network along grain boundaries polymer, which increase from mechanical strength properties such hardness and wear.

5- The air bubbles were clear in optical microscopy, SEM formed in pure polymer due to the hand mixing. And it is reduced or disappear in composite polymer.

6- The Optical microscopy, SEM and EDX analysis for In vitro test using $\mathrm{SBF}$ shows the growth of HAp layer with increasing in concentration of $\mathrm{Ca}$ and $\mathrm{P}$ elements formed on the surface for second sample, this shows good results proof the biocompatibility of the polymer sample.

7- A femoral ball head of implant system in human body drawn by using solid work program use 3D printer to production model femoral ball head of hip implant system from best composite materials $(90 \%$ PMMA + 8\% Zr + 2\% HAp).

\section{References:}

[1] Harper, Charles A., Handbook of Plastic Processes, John Wiley \& Sons, pp. 100-113, 2005.

[2] F. Zivic, M. Babic, G. Favaro, M. Caunii, N. Grujovic, S. Mitrovic, Microindentation of Polymethyl Methacrylate (PMMA) Based Bone Cement, Tribology in industry, Volume 33, No. 4, 2011.

[3] Asopa V, Suresh S, Khandelwal M, Sharma V, Asopa S S, Kaira L, A Comparative Evaluation of Properties of Zirconia Reinforced High Impact Acrylic Resin with that of High Impactacrylic Resin: Saudi J Dent Res Volume 6, pp.146 - 151, 2015.

[4] Z Hasratiningsih, V Takarini, A Cahyanto, Y Faza, L A T W Asri, and B S Purwasasmita, Hardness evaluation of PMMA reinforced with two different calcinations temperatures of $\mathrm{ZrO} 2-\mathrm{Al} 2 \mathrm{O} 3-\mathrm{SiO} 2$ filler system, IOP Conf. Series: Materials Science and Engineering,Volume $172,2017$.

[5] Shinzato S,Nakamora T,Kokubo T,Commosite consist of polymer PMMA and alumina powder :an evaluation of their mechanical and biological properties ,J.Biomed Mater, vol.4, 2002.

[6] D.E. Discher, P. Janmey, Y. Wang, Tissue Cells Feel and Respond to the Stiffness of Their Substrate, Science, vol. 310, pp. 1139-1143,2016.

[7] Vopat B, 2radhika N, 3jibin C Vincent, 4vivekananthan B, 5gnanavel S ;" Invitro Study Of Ti-6Al-4V Alloy Coated With HAp By Physical Vapour Deposition (E-Beam) Method And Hap By Rf Sputtering Method For Orthopaedic Application "; Proceedings Of 42nd Irf International Conference, 15th May, 2016, Chennai, India, Isbn: 978-93-8608317-3.

[8] Vopat B, Paller D, Machan JT, Effectiveness of low profile supplemental fixation in anterior cruciate ligament reconstructions with decreased bone mineral density. Arthroscopy, vol .29,no(9)p.p:1540-1545 ,2013.

[9] Arisara Thavee deetrakul and Virote Boonamnuayvitaya, Apatite Deposition on $\mathrm{ZrO}_{2}$ Thin Films by DC Unbalanced Magnetron Sputtering, Advances in Materials Physics and Chemistry Supplement: 2012 world Congress on Engineering and Technology.

[10] C. Piconi, G. Maccauro, Zirconia as a ceramic biomaterial, Biomaterials, vol. 20, pp. 1-25, 1999.

[11] Emre G, Akkus A, Karamış M B, Wear resistance of Polymethyl Methacrylate (PMMA) with the Addition of Bone Ash, Hydroxylapatite and Keratin, IOP Conf. Series: Materials Science and Engineering, vol,295, 2018.

[12] Wesam Abdali, Dunya Abdulsahib Hamdi and Fahad Mohanad Kadhim, Reinforcement of Poly (Polymethylmethacrylate) With Carbon Fiber and Alumina as a Composite Material for Orthopedic Implant, International Journal of Mechanical Engineering and Technology (IJMET) Vol. 9, Issue 10, pp. 388-398, October 2018.

[13] J. D. Enderle, J.D. Bronzino, S. M. Blanchard., Introduction to biomedical engineering, Elsevier Academic Press, 2005

[14] Z. Hasratiningsih, V. Takarini, A. Cahyanto, Y. Faza, L. A. T. W. Asri, and B. S. Purwasasmita" Hardness evaluation of PMMA reinforced with two different calcinations temperatures of $\mathrm{ZrO}_{2}-\mathrm{Al}_{2} \mathrm{O}_{3}$ $\mathrm{SiO}_{2}$ filler system" IOP Conf. Series: Materials Science and Engineering vol,172,2017.

[15] Emre G, Akkus A , Karamış M B" Wear resistance of Polymethyl Methacrylate (PMMA) with the Addition of Bone Ash, Hydroxylapatite and Keratin "IOP Conf. Series: Materials Science and Engineering vol,295,(2018.

[16] Dunya Abdulsahib Hamdi" Investigating The Mechanical And Microstructure Properties Of Ceramic- PMMA Polymer Composite "AIP Conference Proceedings 2213, 020043 ,(2020)

[17] Wang M. Developing bioactive composite materials for tissue replacement. Biomaterials, vol.24, pp:2133-2151, 2003. 
NJES23(4)331-337, 2020

Rasheed \& Hamdi

[18] Ayesha Ali Fadhil, " Investigation of Mechanical properties for Hybrid Polymer Composite Materials" M.Sc. Thesis, Al-Nahrain University, College of Engineering, Mechanical Engineering department, 2015.

[19] Dunya Abdulsahib Hamdi "Study The Structure of Hydroxapatite Reinforced by Carbon Nanotube

Coated Ti Alloy" International Journal of Mechanical Engineering and Technology (IJMET) Volume 9, Issue 9, pp. 1010-1021, September 2018.

[20] Shinn-Jyh Ding "Properties and immersion behavior of magnetron-sputtered multi-layered hydroxyapatite/titanium composite coatings" Journal of Biomaterials, vol.24, pp.4233- 4238,2013. 